\title{
Does development deter crime against women? Panel evidence from India
}

\author{
Suhasini Gupta \\ School of Economics, SMVD University, Jammu, India \\ Pradeep Kumar Sahoo \\ Department of Social Work, Utkal University, Bhubaneswar, India, and \\ Kirtti Ranjan Paltasingh \\ School of Economics, SMVD University, Jammu, India
}

\begin{abstract}
Purpose - This paper investigates the deterrence effect of development on crime against women in India. Specifically, the authors examine the deterrence effect of the composite development index, i.e. Human Development Index (HDI), along with other variables acting as development indicators such as women's employment, the relative strength of women in the police force, urbanization, etc., on crimes against women. Design/methodology/approach - This study adopts a fixed effect within-group (WG) panel regression model and pooled regression model on the data of 28 states over 20 years from 2000 to 2019. For checking the robustness of the results, the authors use the estimation from the system generalized method of moments.

Findings - The results confirm the deterrence effect of development as measured by the HDI and female labor force participation on various crimes against women. In addition, female feticide representing the socio-cultural attitude toward women turned out to be another significant determinant of almost all types of crime against women. Further, the study also finds the deterrence effect of variables such as police expenditure, the relative strength of women in the police force, urbanization and arrest rate on various crimes against women.

Originality/value - This research paper is unique because it tries to examine the deterrence hypothesis of development by taking a composite index of development, i.e. HDI and other variables at the state level in the Indian union.
\end{abstract}

Keywords Crime against women, HDI, Deterrence hypothesis, Panel data

Paper type Research paper

\section{Introduction}

The rising crimes against women, especially against minors and young girls and women in various parts of India, have become the biggest challenge for the state. This presents a clear picture of how women and young girls are treated in Indian society. The horrific rape and murder of a 19-year-old Dalit girl [1] in Hathras of Uttar Pradesh in 2020 and also the rape of a 16-year-old in the same state [2], rape and murder of an 8-year-old in 2018 and an 11-year-old girl in 2019 in the states of Jammu \& Kashmir [3] and Gujarat [4], respectively, are the few

\section{JEL Classification - C22, C23, K14}

(C) Suhasini Gupta, Pradeep Kumar Sahoo and Kirtti Ranjan Paltasingh. Published in Journal of Business and Socio-economic Development. Published by Emerald Publishing Limited. This article is published under the Creative Commons Attribution (CC BY 4.0) licence. Anyone may reproduce, distribute, translate and create derivative works of this article (for both commercial and non-commercial purposes), subject to full attribution to the original publication and authors. The full terms of this licence may be seen at http://creativecommons.org/licences/by/4.0/legalcode

The authors are thankful to the two anonymous reviewers and the Editor of this journal for many insightful comments that improved the content of the paper. However, the usual disclaimer applies.

Funding: No funding was received for this research.

Declaration: The authors declare that there is no potential conflict of interest.

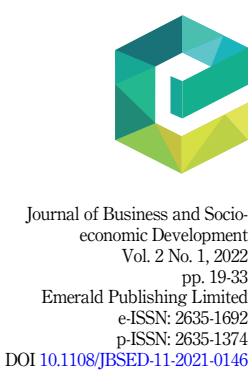

Received 4 November 2021 Revised 9 January 2022 6 February 2022

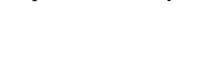

(1)


JBSED 2,1

incidents that shook the moral conscience of the nation. This is just to mention a few horrific cases of violence against women and young and minor girls in India.

Crime against women traces its origin to a male-dominated society where the males control the community's socio-economic, political and legal order (Himabindu et al., 2014; Basu-Roy and Ghose-Dastidar, 2018). The patriarchal system perpetuates gender inequality where men and women are treated differently and governed by different sets of social rules that legitimize the violence against women (Russo and Pirlott, 2006). Though worldwide gender-based violence affects one-third of women (United Nations (UN), 2013), India ranks lower when compared with other developing and developed nations in the world [5]. The findings of various research-based reports give testimony to this above fact. For instance, Thomson Reuters Foundation in 2018 stated that India is the world's most dangerous country for women. Every three minutes, a crime against women got recorded and every $60 \mathrm{~min}$, four rape cases occurred in 2017 as compared to two in 2007 (National Crime Record Bureau (NCRB), 2018). Another report depicts that more than 8,000 women died due to dowry harassment in 2015 alone (NCRB, 2017). Although the police have charge-sheeted around $93.7 \%$ of the accused, yet only $34.7 \%$ have been convicted. The cases of sexual violence that go unreported account for $99 \%$ of the total cases. According to the National Crime Record Bureau (NCRB) report, the crime rate against women per 100,000 female populations increased from $41 \%$ in 2012 to $55.2 \%$ in 2017 (NCRB, 2018). Though these figures represent only the reported crimes, they reflect a steady rise in crimes against women.

Despite the prevalence of these felonies, India suffers from lack of empirical studies regarding "Crime against Women." Most of the studies using NCRB data dealt with rape and domestic violence, ignoring the other types of crime against women, such as molestation, eveteasing, abduction and kidnapping, importation of young girls and women, etc. Again, some studies in India as well as abroad have examined the effect of some socio-economic indicators on crimes such as economic growth (Cárdenas, 2007; Gaibulloev and Sandler, 2008), education (Hazra, 2020 [6]; Lochner and Moretti, 2004; Dreze and Khera, 2000), unemployment (Hazra, 2020; Imran et al., 2018; Jalles and Andresen, 2017; Hamzah and Lau, 2011; Fafchamps and Minten, 2006), gender and demography (Dreze and Khera, 2000; Basu-Roy and Ghose-Dastidar, 2018), political representation in local government (Pande, 2003; Bardhan et al., 2010; Clots-Figueras, 2011; Iyer et al., 2012), good governance (Habibullah et al., 2016) [7] and so on.

These variables constitute different indicators of development. However, none of these studies except one by Hackett (2011) has ever attempted to examine the crime deterrence effect of development by taking into account different development indicators together with the help of a composite index. Hackett (2011), using the weights from factor analysis, constructed three development indicators like gender development, human development and urban development and estimated the impact of these development indicators dowry deaths and cruelty of husbands. Some recent studies in the context of India by Basu-Roy and GhoseDastidar (2018) and Lolayekar et al. (2020) and some others also looked at the determinants of crimes against women. While Basu-Roy and Ghose-Dastidar (2018) is restricted to only rape cases, Lolayekar et al. (2020) used the district-level panel data on various crimes against women. However, this present study differs from the entire literature on several grounds. First, we test the deterrence effect of development on crimes against women by taking a wellknown composite index of development, i.e. Human Development Index (HDI), at the subnational level. Second, along with HDI, we also incorporate other development indicators such as female labor force participation, the relative share of women personnel in the police force, urbanization, female feticides, etc., to examine that hypothesis.

With this objective, the paper is organized in various sections: after a brief introduction in the first section, we discuss the data and methods in the second section. The third section 
deals with the recent trends and patterns of crime and compares various crimes with many development indicators. The fourth section discusses the empirical results, followed by robustness checking. Finally, the study concludes with some policy implications.

\section{Recent trends and pattern of crimes against women}

The incidence of crime against women has risen drastically in the past few years, reflecting their increasingly miserable status in society. This increasing trend can be attributed to many factors such as the lengthy judicial process, societal taboos and stigmatization of the victims, increasing criminalization of politics and the continuous status of misery in society, political apathy to implement gender-sensitive laws and policies, lack of will for strengthening and reforming police with more female personnel. In 2018, India's ranking on the Gender Development Index was 129 out of 189 countries (GDI, 2019, UNDP). Figure 1 shows that the trends of incidences of crimes like eve-teasing, molestation, cruelty by husbands and relatives, dowry deaths, and rape, kidnapping and abduction of women have increased in India from 1995 to 2019. As per NCRB report (2018), the highest number of cases recorded under cruelty by husband or his relatives $(27.9 \%$ ) followed by "assault on women with intent to outrage her modesty" (21.4\%), "kidnapping and abduction of women" $(21.3 \%)$ and "rape" $(6.6 \%)$. Under kidnapping and abduction, a total number of 105,734 cases were recorded in 2018 , increasing more than $10 \%$ over last year (95,893 in 2017). Yet again, out of the total cases of kidnapping and abduction, around $77 \%$ are females $(80,871)$, and in that total number of females, about $60 \%$ are young girls. The number of rape cases reported in 2018 was 33,977, an increase of $4.35 \%$ over the previous year (32,559 in 2017). Among the total rape cases, the distributional pattern by age cohorts shows a shocking picture. Nearly $1 \%$ of the victims (281) are, in fact, kids below six years of age, $2.2 \%$ (757) belong to the age group of 6 12 years, around $11 \%$ of the victims (3,618) are from the age group of $12-16$ years and $14.06 \%$ $(4,779)$ belong to $16-18$ age group. So a total of around $28 \%$ of rape victims $(9,433)$ are below 18 years, $52 \%(17,636)$ belong to the $18-30$ years age group and $20.3 \%(6,908)$ belong to the age group of more than 30 years old. These statistics are highly understated as they are police-reported cases. Besides that, the cases like gang rape, marital rape, etc., are not included under official statistics of crime against women (Himabindu et al., 2014). On the other

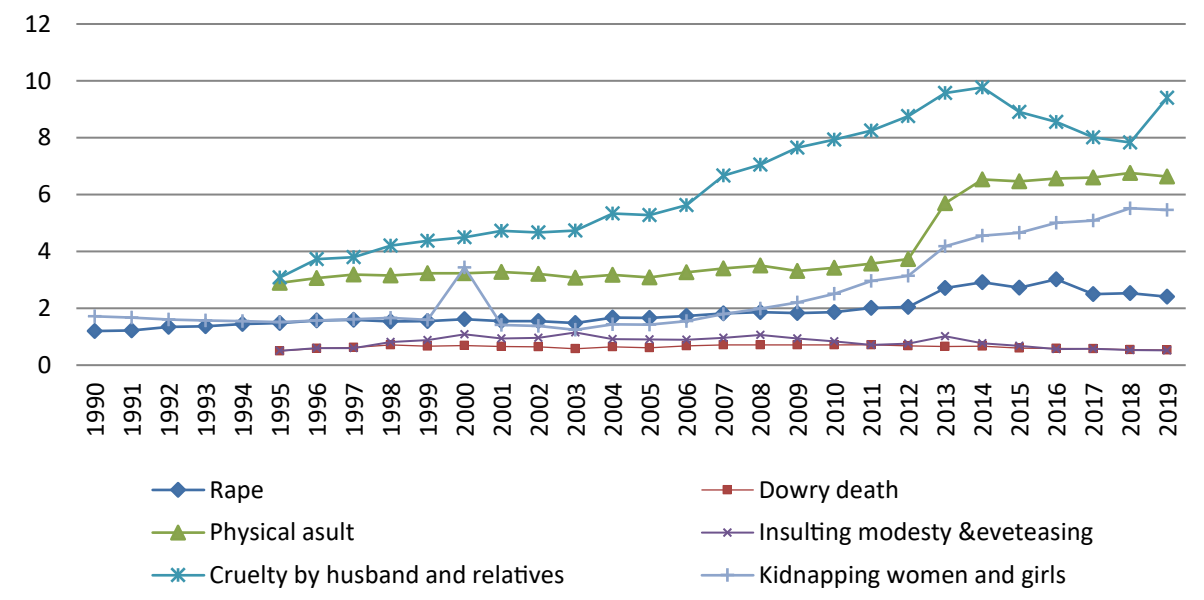

Source(s): National Crime Record Bureau, New Delhi
Does
development
deter crime
gainst women?

21
Figure 1.

Incidence of various types of crimes against women (in thousands) 
JBSED 2,1

hand, the number of reported cases for the importation of girls for coerced intercourse has slightly decreased from 2000 to 2017.

Table 1 compares the average HDI figures and the incidence of various crimes along with the rate of conviction and relative strength of women in the police force. Two serious points we observed. First, the north zone has topped in the incidence of every type of crime against women and ironically it also holds relatively higher $\mathrm{HDI}$ values (0.61). Also, both the average conviction rate and relative strength of women in the police force are relatively high in the north zone. Second, the east zone has a higher incidence of every type of crime except kidnapping and correspondingly, it has the lowest value of $\mathrm{HDI}$ as well as conviction rate and relative strength of women in the police force. So this apparently depicts a pattern that development encourages more reporting of the cases, paving the way for a higher conviction rate. We can also argue that because of the high conviction rate and the presence of more women in the police force, the reporting of the cases tends to be more. The south zone follows the north zone as it ranks second in the incidence of crimes and holds the highest value of HDI and the highest presence of women in the police force.

\section{Materials and methods}

3.1 Data and variables

Data on six types of crime against women such as rape, molestation, eve-teasing, dowry deaths, sexual harassment and importation of girls and cruelty by husbands and relatives are taken from the annual reports of the NCRB, Government of India, for the period 2001-2019 on 28 states of the Indian Union. The NCRB records only police-reported crimes. Therefore, there is a fear of mismeasurement of crime statistics in crime literature, affecting the reliability of results (Amaral et al., 2015). However, the common practice of taking data on gender-based violence is either considering the police reported crimes (Iyer et al., 2012), or surveyed domestic violence (Amaral et al., 2015; Bobonis et al., 2013), or hospitalization of household assaults (Aizer, 2010). These measures represent different levels of women empowerment and various states of household conflicts (Amaral et al., 2015). In this study, we use police-reported crimes from NCRB data. However, Iyer et al. (2012) and Sekhri and Storeygard (2015) argued that dowry deaths are relatively more reliable as it is tough to hide or under-report the incident. Here, we have taken dowry deaths and other crimes against women under the legal system of the Indian Penal Code (IPC). The empirical analysis is based on the rate of crime which is defined as the number of crimes per million population that has occurred in a given geographical region [8].

Moreover, the NCRB reports also provide data on pendency rate of cases, expenditure on police training and infrastructure, the number of female personnel in the total police force, total persons under investigation, total persons arrested, total persons convicted, total persons under trial and total persons charge-sheeted for IPC crime categories and female feticides. The data on sub-national HDI figures and the percentage of people living in urban regions (urbanization) are compiled from a database called "Global Data Lab [9]." The variables like the proportion of Scheduled Caste (SC) and Scheduled Tribe (ST) population are collected at different time points from Census India data and interpolated [10] to get historical data for all the states. Similarly, data on women employment in public and private sectors are collected from National Sample Survey Office every five-year interval and interpolated to have continuous time-series data for states. Table 2 presents the definition and descriptive statistics of all the variables included in the analysis.

\subsection{Empirical strategy}

The panel regression analysis has been used in this study, considering transversal information and the period from 2001 to 2019. It contains information on inter-temporal 


\begin{tabular}{|c|c|c|c|c|}
\hline \multirow{4}{*}{$\begin{array}{l}\text { JBSED } \\
2,1\end{array}$} & Variable & Mean & S.D. & Definition \\
\hline & RAPE & 0.43 & 0.21 & Rate of rape (number of rape cases per one million population) \\
\hline & MOL & 4.16 & 2.13 & Rate of molestation (number of cases per one million population) \\
\hline & KA & 0.51 & 0.12 & $\begin{array}{l}\text { Rate of kidnapping and abduction of young girls and women (number of cases per } \\
\text { one million population) }\end{array}$ \\
\hline \multirow{13}{*}{24} & EVE & 0.81 & 0.11 & Rate of eve-teasing (number of cases per one million population) \\
\hline & $\mathrm{DD}$ & 0.06 & 0.09 & Rate of dowry deaths (number of cases per one million population) \\
\hline & $\mathrm{CHR}$ & 0.64 & 0.18 & $\begin{array}{l}\text { Rate of cases involving cruelty by husbands and relatives (number of cases per one } \\
\text { million population) }\end{array}$ \\
\hline & HDI & 0.59 & 0.06 & Human development index of all states of India (0-1 range) \\
\hline & POLE & 6.57 & 1.32 & $\begin{array}{l}\text { Expenditure on police training and infrastructure as a percentage of the total state } \\
\text { budget }\end{array}$ \\
\hline & PND & 2.87 & 1.03 & Pendency rate of cases $(\%)$ \\
\hline & WEM & 4.76 & 1.3 & Women employment in public and private sectors $(\%)$ \\
\hline & CONV & 0.27 & 0.63 & Rate of conviction (total persons convicted/Total persons under trial) \\
\hline & ARST & 0.67 & 4.48 & Rate of arrest (total persons arrested/Total persons charge-sheeted) \\
\hline & PSW & 0.38 & 1.75 & Relative strength of women in the police force (female/Male) (\%) \\
\hline & URB & 0.46 & 0.3 & Rate of urbanization (urban to rural population) \\
\hline & $\mathrm{SC}$ & 3.06 & 1.01 & Percentage of SCs and STs in total population (\%) \\
\hline & $\mathrm{FF}$ & 3.78 & 7.9 & Number of female feticide cases per lakh female population \\
\hline
\end{tabular}

Table 2.

Note(s): \# indicates that the individual crime rate is used as the dependent variable in the empirical models concerning that crime

Descriptive statistics of Source(s): Author's calculation from NCRB data, Indiastat.com, Population and Vital Statistics, Handbook of variables Indian Statistics, Reserve Bank of India (RBI)

dynamics as well as individual specificities of entities. Furthermore, the panel dataset has a specific feature to control for heterogeneity in data. All the 28 states are heterogeneous and vary in socioeconomic and geographical attributes. Thus, the panel data regression model provides more reliable and accurate estimates. After conducting the Hausman test [11] for different crime-wise estimations (Appendix Table A1),we find the appropriateness of the "fixed-effect model" (FEM). However, we have a small sample by definition as the period $(T)$ is less than the number of states $(N)$. To avoid the state dummies that consume too many degrees of freedom, we use the fixed effect within-group (WG) estimator. Besides, many additive and multiplicative dummies for the states may lead to possible multicollinearity problems (Gujarati, 2015, p. 332). In the fixed-effect WG model, the entire equation is written as a deviation from their respective group mean values and regression is run on mean corrected variables. To start with the following equation:

$$
C_{i t}=\alpha_{0 i}+X_{S, i t} \beta_{S}+X_{P, i t} \beta_{P}+X_{D, i t} \beta_{D}+X_{C, i t} \beta_{C}+\varepsilon_{i t}
$$

where $C_{i t^{-}}$crime against women in the state $i$ at time $t . X_{S, i t}$ is the vector of socioeconomic development variables such as development index $\left(H D I_{i t}\right)$ for states, women employment in public and private sectors $\left(W E M_{i t}\right)$, etc., $X_{p, i t}$ represents the vector of variables relating to police force/action and judiciary. It includes variables such as total expenditure on police training and police infrastructure $\left(P O L E_{i t}\right)$, the relative strength of women in the police force $\left(P S W_{i t}\right)$, pendency percentage of legal cases $\left(P N D_{i t}\right)$; the rate of conviction $\left(C O N V_{i t}\right)$ and rate of arrest under these crimes $\left(A R R S T_{i t}\right)$ for state $i$ at time $t . X_{D, i t}$ is the vector of demographic characteristics such as the percentage of SCs and STs in the total population [12] $\left(S C_{i t}\right)$, rate of urbanization $\left(U R B_{i t}\right) ; X_{C, i t}$ is the vector of cultural variable like the number of female feticide cases $\left(F F_{i t}\right)$ for state $i$ at time $t$, which captures the social attitude toward women or valuing of women in Indian society, $\alpha_{0 i}$-individual effects; $\varepsilon_{i}$ is a cross-section or individual-specific component. 
Now taking the sum of this Eq. (1) on both sides and dividing by $T(=19)$, we get:

$$
\frac{1}{19} \sum_{t=1}^{19} C_{i t}=\frac{1}{19}\left[\sum_{t=1}^{19}\left(\alpha_{0 i}+X_{S, i t} \beta_{S}+X_{P, i t} \beta_{P}+X_{D, i t} \beta_{D}+X_{C, i t} \beta_{C}+\varepsilon_{i t}\right)\right]
$$

Since the parameters do not change over time, this reduces to

$$
\bar{C}_{i}=\alpha_{0 i}+\bar{X}_{s, i} \beta_{S}+\bar{X}_{p i} \beta_{P}+\bar{X}_{D i} \beta_{D}+\bar{X}_{C i} \beta_{C}+\bar{\varepsilon}_{i}
$$

This bar over each variable indicates its average values over 19 years. For this, we have 28 states $(i=28)$, average values for each variable belonging to 28 states. Now subtracting Eq. (3) from Eq. (1), we get the final WG estimator where the fixed or individual effect intercept term $\alpha_{0 i}$ drops out, as:

$$
C_{i}-\bar{C}_{i t}=\left(X_{S i t}-\bar{X}_{S i}\right) \beta_{S}+\left(X_{P i t}-\bar{X}_{P i}\right) \beta_{P}+\left(X_{D, i t}-\bar{X}_{D i}\right) \beta_{D}+\left(X_{C, i t}-\bar{X}_{C, i}\right) \beta_{C}+u_{i t}
$$

This WG estimator uses the time variation within each cross-sectional unit and provides consistent estimators of the parameters. Interestingly, the estimators obtained from this method are identical to the estimators from the FEM because, mathematically, both approaches are identical, except the WG model is free from the state dummies that consume more degrees of freedom (Gujarati, 2015, p. 333). Though this method has a limitation of removing the impact of time-invariant regressors, there is no time-invariant regressor in our model. So this is the most appropriate method for empirical analysis in this study. We also estimated the pooled regression model side by side for comparison and robustness of results. The estimation of a generalized method of moments (GMM) developed by Arellano and Bond (1991) is also undertaken for a similar purpose for individual crimes. This method usually begins by transforming all the regressors by differencing as:

$$
\Delta C_{t}=C_{t-1}+\Delta X_{S i t} \beta_{S}+\Delta X_{P i t} \beta_{P}+\Delta X_{D, i t} \beta_{D}+\Delta X_{C, i t} \beta_{C}+u_{i t}
$$

Then the relationship is examined in a dynamic setup based on lagged levels of variables as instruments in the first differenced equation.

\section{Results and discussion}

Before looking into the influence of all these variables on crime against women, we tested their stationarity. All variables except $\mathrm{HDI}$ and the urban ratio of population are stationary at level (Appendix Table A2). There may be an endogeneity bias in the model because of reverse causality [13]. So, we conducted the Durbin-Wu-Hausman (DWH) test for endogeneity which confirms the absence of endogeneity in the model. We also adopted the robust standard error consistent estimator (Huber-White standard error), which controls for heteroskedasticity and serial correlation without altering the value of coefficients.

\subsection{Determinants of crime against women: crime wise analysis}

This section presents a crime-wise analysis where the determinants of individual crimes are estimated using the same panel FE-WG model. Here the crime rate in each category is taken as the dependent variable. Table 3 shows the results for various crimes against women. The results show that HDI positively and significantly affects every crime except dowry deaths and cruelty by husbands. The positive influence of $\mathrm{HDI}$ on all crimes like rape, molestation and eve-teasing shows the reporting effect as discussed earlier. In fact, these are heavily underreported crimes. Thus, this indicates a better reporting effect. But the significant 
JBSED

2,1

26

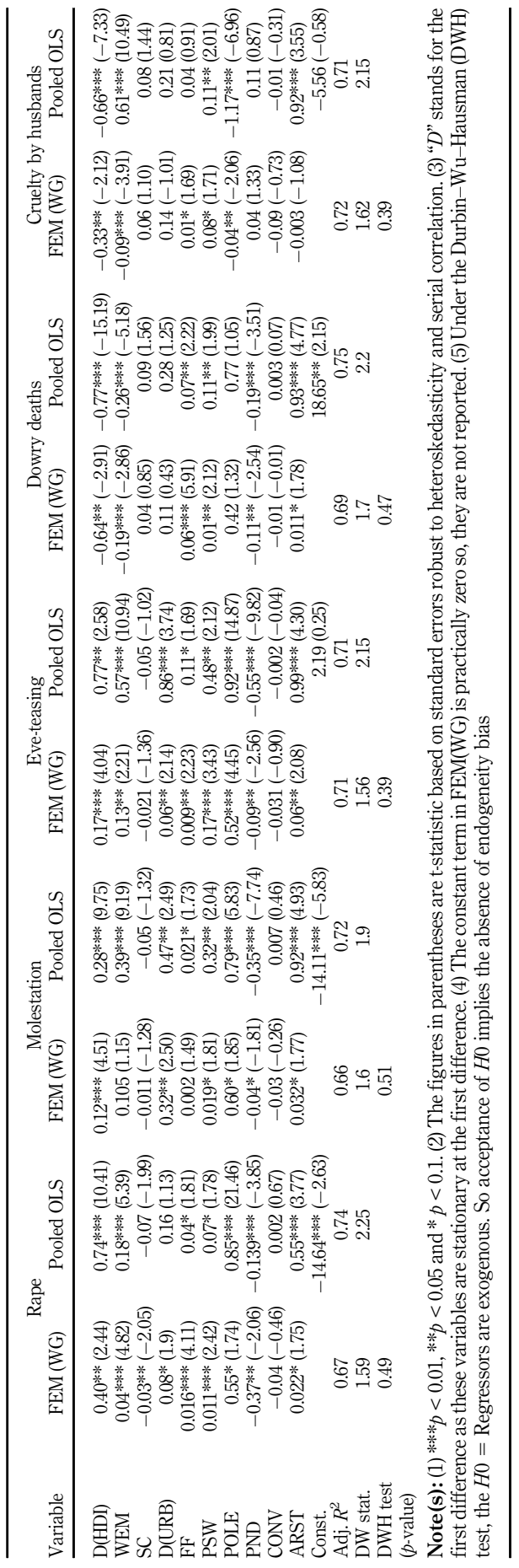

Table 3.

Fixed effect (withingroup) and pooled OLS estimates for determinants of crime rates against women in India 
negative effect in the case of dowry deaths and cruelty by husbands suggests the deterrence effect of development because these crime figures are relatively reliable as it is difficult to hide the information (Iyer et al., 2012; Sekhri and Storeygard, 2015). It indicates that as development takes place in the form of better education, health facilities and improved per capita income, employment opportunities, etc., it leads to more self-reporting of the cases. This is, in fact, the first step toward crime deterrence since reporting of the crimes needs to be augmented before being deterred. The reporting of cases leads to better law and order enforcement, leading to a fall in the incidence of crime against women.

A similar impact is also observed in the case of women employment in both private and public sectors, where it exerts a significantly positive effect in the case of rape, molestation and eve-teasing, but a significantly negative impact in the case of dowry deaths and cruelty by husbands or his relatives. Chakraborty et al. (2018) also argued that women's labor force participation is inversely related to crime against women through a higher reporting effect. At the same time, as Chin (2012) argues, the empowerment effect due to female employment is larger than the male dominance effect, leading to more self-reporting of crimes. Empowered women are quick to report the crime and it is more so if the women are low-wage earners and hail from relatively low-income families (Mukherjee et al., 2001). It is because her participation in the labor market counts more than the efforts to maintain chastity and avoid stigmatization of sexual harassment.

Two arguments from crime literature support the positive influence of HDI and women employment on reported crime rates. First, some studies argue that changing the economic status of women leads to enhancement of the well-being of women and girl children, thereby augmenting their bargaining power in household decision-making and also in society. Hence, it paves the way for more self-reporting of the cases as well as an increase in sexual harassment (Luke and Munshi, 2011; Eswaran and Malhotra, 2011). Eswaran and Malhotra (2011) showed that wage income exerts a greater impact on female autonomy and non-labor income. This empowerment leads to either higher domestic violence or greater self-reporting of the crimes outside households. Amaral et al. (2015) found that the introduction of "National Rural Employment Guarantee Scheme" in 2006, the world's largest anti-poverty program, has, indeed, enhanced the female labor force participation [14] in India, which has been found associated with increased sexual harassments and domestic violence. But dowry deaths have declined. Because of their labor force participation, there is increased interaction between men and women in unorganized sectors. So it sometimes results in increased sexual harassment as well as reporting of such cases.

The factors like urbanization, relative female strength in the police force, arrest rate, etc., also positively affect various crime rates. However, the positive impact of urbanization can be understood in both ways. First, economic prosperity augments the reporting of cases as people become more assertive and aware of it. But, at the same time, it also brings more opportunities for the women, enhances their labor participation and in turn, makes them more exposed to the risk of sexual harassment both at the workplace as well as during their daily commute to the workplace (Gangopadhyay, 2015). From the results, we observe a significant positive impact of urbanization on crimes like rape, eve-teasing, molestations, etc. But, it does not significantly affect the incidence of dowry deaths and cruelty by husbands and relatives. This supports Mc-Ilwaine's (2013) argument that women face less risk of domestic violence by partners in urban areas than rural areas. But, they face a higher risk of violence by nonpartners in urban areas. In fact, the poor women in urban areas are subject to more violence because of their insecurity. They live in slums with a makeshift arrangement, making them more vulnerable to theft, rapes with little recourse to protection.

The positive and significant influence of the female feticide variable clearly shows a denigrated socio-cultural attitude toward girls and women in society. This is a significant contributor to crimes against them. It represents the selective illegal abortion of female 
JBSED

2,1

28

fetuses rampant in India and points toward the regressive social order where the son is considered an asset, but girl is a burden. This cultural norm, which approves violence at this stage, also increases the likelihood of crimes against women in the future (Basu-Roy and Dastidar, 2018). Therefore, a low sex ratio due to female feticide is always associated with higher crimes against women.

More female strength in the police force is positive and quite significant, revealing its deterrence effect through higher reporting of crimes against women. However, in India, the relative strength of women in the police force is around 7-8\%, making it difficult to get the cases reported and recorded. So the low reporting and recording effect is due to this reason as the law permits that only the female officers register the victim's statement and help her medically and legally (Himabindu et al., 2014).

Among the other legal deterrence factors, the percentage of pending cases, arrest rate and police expenditure significantly influence various crime rates. While the percentage of pending cases adversely affects the crime rates, the other two positively and significantly influence various crimes against women. The negative influence of pending cases indicates the delay in the justice process, resulting in more crimes against women because it emboldens the potential culprits. However, the arrest rate renders deterrence on crime by augmenting the reporting effect. On the other hand, the conviction rate is insignificant. It's because the low and long judicial process makes it difficult to solve a case quickly within a stipulated time. Hence, its effectiveness dies out in the long-run. Moreover, sometimes due to delay, victims also face life threats from the culprits and deny giving statements in the court. So the conviction rate as a legal deterrent loses its effectiveness.

\subsection{Robustness check}

We also re-estimated the results using a pooled regression model with the Huber-White robust standard error to check the results' robustness. The results of the pooled regression model for various crimes are reported along with the results of FEM (WG) in Table 3. These pooled regression results almost follow the trend of FEM (WG) results. All the variables of interest, such as HDI, WEM, URB, SR, PSW, ARST, etc., carry the same sign and statistical significance. Again, to make the results more reliable for comparison, we estimated the first differenced-GMM model that takes care of the endogeneity problem in the model. The results for all individual crimes are presented in Table 4. These results also confirm the broad trend in earlier main results. From Table 4, we observe that all major variables such as HDI, WEM, URB, PEXP, PND and ARST significantly influence individual crime categories. Their coefficients also carry the signs in line with theoretical intuition. Hence, these GMM results entirely follow the pattern of earlier results, ensuring their robustness.

\section{Conclusion with policy implication}

In this study, we examined the deterrence effect of HDI, women labor force participation, relative strength of women in the police force and other determinants on crime against women. HDI was found to be a significant and positive determinant for most of the reported crime categories. It empirically validates the hypothesis that development encourages women to report crimes in the police station. Again, female labor force participation also renders similar effects on crime against women. Thus, the reporting effect of socioeconomic development on crime against women is quite significant. The other variables like female feticide, women ratio in the police force, percentage of pending cases, rate of arrest, etc., significantly influence the crimes against women. However, we find a negative and significant impact of HDI and women employment on dowry deaths and cruelty by husbands. 


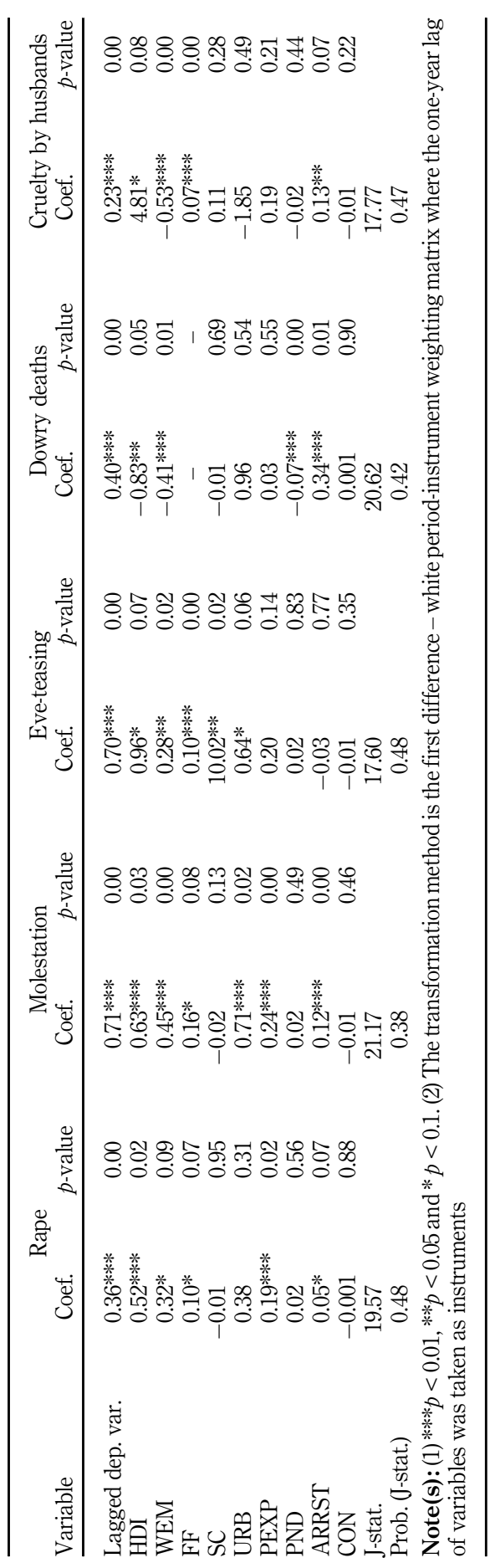

Does development deter crime against women?

29 Table 4 GMM estimations of determinants of crime rates 
JBSED 2,1

So the positive effects of HDI and women's employment in the case of various crimes reveal the deterrence effect of development in the form of more reporting of crimes. But, the significant negative impact of the same variables in the case of dowry-related cases and cruelty by husbands and relatives signifies the direct deterrence effect.

The policy suggestion of the study calls for well-coordinated efforts and investments by the public authority on crime deterrence using a variety of tools like female and girls education, raising their labor force participation, making the police force more efficient, etc. Enhancing girls' education, especially higher education, will be a vital strategy to deter crime against women. This has spillover effects on their labor-force participation and ultimately paves the way for their enhanced socio-economic bargaining power in society. Augmenting the relative strength of women's representation in the police force and increasing the efficiency of the criminal justice system would also encourage more reporting of cases rendering a faster investigation and higher rate of arrest, conviction and prosecution. A special cell headed by a lady officer should be instituted in every major police station to boost the reporting of crimes and avoid the unnecessary harassment of victims at the time of reporting.

\section{Notes}

1. One 19-year-old Dalit girl was gang raped and murdered on 14 September 2020 in a village of Hathras, Uttar Pradesh. This most horrendous act was carried out by four men and her cremation was horribly conducted by the police in the night without the presence of any of her family members to avoid widespread protest (The Indian Express, 15 September, 2020).

2. A 30 years old man in Sambhal district of Uttar Pradesh raped and murdered a girl by pouring kerosene and setting fire on her in November 2019 (Times of India, 23 November 2019).

3. In Kathua district of Jammu and Kashmir, an 8-year-old girl got abducted, raped and killed by eight people in April 2018 which shocked the moral conscience of the nation.

4. A two and half year minor was abducted, raped and killed in Ahmadabad in December 2019.

5. Gender equity is one of the sustainable development goals (SDGs) which is far from its targeted level (Adeosun and Owolabi, 2021). India's performance on this front is miserable.

6. Hazra (2020) has taken a total crime rate which is the sum of crime rates under Indian Penal Code (IPC) and Special and Local Laws (SLL). But she has included many crimes against women.

7. Though, Habibullah et al. (2016) have not exclusively analyzed the role of good governance in crime deterrence, but they have taken total crimes where the specific crimes against women are included.

8. Originally, the rate of crime is defined in NCRB reports as the number of crimes per one lakh $(0.1$ million) population. But the standard procedure in the crime literature follows the definition of crime rate per one million populations. So we converted it.

9. This Global Data Lab is developed and maintained by Nijmegen Center for Economics (NiCE), Radboud University, the Netherlands. It can be accessed at https://globaldatalab.org/areadata/.

10. The general interpolation method, having two data points $\left(x_{a}, y_{a}\right)$ and $\left(x_{b}, y_{b}\right)$ is expressed as: $y=y_{a}+\left(y_{b}-y_{a}\right) \frac{x-x_{a}}{x_{b}-x_{a}}$ at data point $(x, y)$.

11. The Hausman test investigates the suitability of fixed effect model vs. random effect model on the basis of $H_{0}: \operatorname{Cov}\left(\lambda_{i}, x_{i t}\right)=0$ against $H_{1}: \operatorname{Cov}\left(\lambda_{i}, x_{i t}\right) \neq 0$ where $y_{i t}=x_{i t} \beta+\varepsilon_{i t}$ and $\varepsilon_{i t}=\alpha_{i t}+\mu_{i t}$. The rejection of $\mathrm{H}_{0}$ implies the suitability of the fixed effect model. The $\mathrm{H}_{0}$ is rejected if calculated $p$-value on the bass of the test statistic $\chi^{2}=\left(\widehat{\beta}_{f e}-\beta_{r e}\right) r\left[V_{f e}-V_{r e}\right]\left(\widehat{\beta}_{f e}-\beta_{r e}\right)$ is less than 0.05 , where variance-covariance matrix of $\beta_{f e}$ and $\beta_{r e}$ are denoted by $\mathrm{V}_{f e}$ and $\mathrm{V}_{r e}$, respectively, and $k$ is the dimension of $\beta$. For details on interpretation, see Gujarati (2015, p. 336).

12. This variable is not included in the model estimation for Northeast zone as STs population holds the majority. 
13. We assume that the factors like improvement in law and order situation may lead to decline in crime. But sometimes increase in crimes or some heinous incidents breaks the conscience of the civil society leading the huge civil movement (as happened in the case of Nirbhaya incident in 2012). This compels the public authority to bring stricter laws and strengthen police by bringing reforms. So there may be a reverse causality flowing from dependent variable (various crimes) toward law and order situation.

14. As per NREGS Act every third person employed under NREGS has to be a female and guarantees equal pay. Hence, it ensures labor demand for women.

\section{Does development deter crime against women?}

\section{References}

Adeosun, O.T. and Owolabi, K.E. (2021), "Gender inequality: determinants and outcomes in Nigeria", Journal of Business and Socio-Economic Development, Vol. 1 No. 2, pp. 165-181, doi: 10.1108/ JBSED-01-2021-0007.

Aizer, A. (2010), "The gender wage gap and domestic violence", American Economic Review, Vol. 100 No. 4, pp. 1847-1859.

Amaral, S., Bandyopadhyay, S. and Sensarma, S. (2015), "Employment programmes for the poor and female empowerment: the effect of NREGS on gender-based violence in India", Journal of Interdisciplinary Economics, Vol. 27 No. 2, pp. 199-218.

Arellano, M. and Bond, S. (1991), "Some tests of specification for panel data: Monte Carlo evidence and an application to employment equations", Review of Economic Studies, Vol. 58, pp. 277-297.

Bardhan, P., Mookherjee, D. and Torrado, M. (2010), "Impact of political reservations in West Bengal local governments on anti-poverty targeting", Journal of Globalization and Development, Vol. 1 No. 1, pp. 1-38.

Basu-Roy, S. and Ghosh-Dastidar, S. (2018), "Why do men rape? Understanding the determinants of rapes in India", Third World Quarterly, Vol. 39 No. 8, pp. 1435-1457.

Bobonis, G.J., Castro, R. and Gonzalez-Brenes, M. (2013), "Public transfers and domestic violence: the roles of private information and spousal control", American Economic Journal, Vol. 5 No. 1, pp. 179-205.

Cárdenas, M. (2007), Economic Growth in Columbia: A Reversal of 'fortune'?, CID Working paper series-83, Harvard University, Cambridge, MA.

Chakraborty, T., Mukherjee, A., Rachapalli, S. and Saha, S. (2018), "Stigma of sexual violence and women's decision to work", World Development, Vol. 103, pp. 226-238.

Chin, Y.M. (2012), "Male backlash, bargaining, or exposure reduction? Women's working status and physical spousal violence in India”, Journal of Population Economics, Vol. 25 No. 1, pp. 175-200.

Clots-Figueras, I. (2011), "Women in politics: evidence from the Indian states", Journal of Public Economics, Vol. 95, pp. 664-690.

Dreze, J. and Khera, R. (2000), "Crime, gender, and society in India: insights from homicide data", Population and Development Review, Vol. 26, pp. 335-352.

Eswaran, M. and Malhotra, N. (2011), "Domestic violence and women's autonomy in developing countries: theory and evidence", Canadian Journal of Economics, Vol. 44 No. 4, pp. 1222-1263.

Fafchamps, Marcel and Minten, B. (2006), "Crime, transitory poverty, and isolation: evidence from Madagascar", Economic Development and Cultural Change, Vol. 54, pp. 579-603.

Gaibulloev, K. and Sandler, T. (2008), "Growth consequences of terrorism in western Europe”, Kyklos, Vol. 61, pp. 411-424.

Gangopadhyay, K. (2015), "Sexual violence: a model of occupational choice and the gender wage gap", Journal of Interdisciplinary Economics, Vol. 27 No. 2, pp. 219-244.

Gujarati, D. (2015), Econometrics by Example, 2nd ed., Palgrave Macmillan, London. 
JBSED 2,1

Habibullah, M.S., Din, B.H. and Hamid, B.A. (2016), "Good governance and crime rates in Malaysia", International Journal of Social Economics, Vol. 43 No. 3, pp. 308-320.

Hackett, M. (2011), "Domestic violence against women: statistical analysis of crimes across India", Journal of Comparative Family Studies, Vol. 42 No. 2, pp. 267-288.

Hamzah, S.N.Z. and Lau, E. (2011), "Is peniaphobia an incentive to crime?", Global Crime, Vol. 12 No. 4, pp. 312-326.

Hazra, D. (2020), "What does (and does not) affect crime in India?", International Journal of Social Economics, Vol. 47 No. 4, pp. 503-521.

Himabindu, B.L., Arora, R. and Prashanth, N.S. (2014), "Whose problem is it anyway? Crimes against women in India", Global Health Action, Vol. 7 No. 1, pp. 1-6, doi: 10.3402/gha.v7.23718.

Imran, M., Hosen, M. and Chowdhury, M.A. (2018), "Does poverty lead to crime? Evidence from the United States of America", International Journal of Social Economics, Vol. 45 No. 10, pp. 1424-1438.

Iyer, L., Mani, A., Mishra, P. and Topalova, P. (2012), "The power of political voice: women's political representation and crime in India", American Economic Journal: Applied Economics, Vol. 4 No. 4, pp. 165-193.

Jalles, J.T. and Andresen, M.A. (2017), "Understanding the relationship between the economy and crime: Canadian provinces, 1981-2009”, International Journal of Social Economics, Vol. 44 No. 9, pp. $1268-1288$.

Lochner, L. and Moretti, E. (2004), "The effect of education on crime: evidence from prison inmates, arrests, and self-reports", American Economic Review, Vol. 94, pp. 155-180.

Lolayekar, A.P., Desouza, S. and Mukhopadhyay, P. (2020), "Crimes against women in India: a districtlevel analysis (1991-2011)", Journal of Interpersonal Violence. doi: 10.1177/0886260520967147.

Luke, N. and Munish, K. (2011), "Women as agents of change: female income and mobility in India", Journal of Development Economics, Vol. 94 No. 1, pp. 1-17.

Mcilwaine, C. (2013), "Urbanization and gender-based violence: exploring the paradoxes in the global South”, Environment and Urbanization, Vol. 25 No. 1, pp. 65-79.

Mukherjee, C., Rustagi, P. and Krishnaji, N. (2001), "Crimes against women in India: analysis of official statistics”, Economic and Political Weekly, Vol. 36 No. 43, pp. 4070-4080.

National Crime Record Bureau (2017), Crime in India: 2017 Statistics, New Delhi.

National Crime Record Bureau (2018), Crime in India: 2018 Statistics, New Delhi.

Pande, R. (2003), "Can the mandated political representation provide disadvantaged minorities' policy influence? Theory and evidence from India", American Economic Review, Vol. 93 No. 4, pp. 1132-1151.

Russo, N.F. and Pirlott, A. (2006), "Gender-based violence", Annals of the New York Academy of Sciences, Vol. 1087, pp. 178-205.

Sekhri, S. and Storeygard, A. (2015), "Dowry deaths: consumption smoothing in response to climate variability in India", Journal of Development Economics, Vol. 111, pp. 212-223.

UN Women: Ending violence against women and girls: Programming essentials (2013), June 2013, available at: http://www.endvawnow.org/uploads/modules/pdf/1372349234.pdf. 


\section{Appendix}

This method is easy and widely adopted, though it has some limitations.

\begin{tabular}{lccc}
\hline Crimes & Estimated Chi-sq. statistic & $p$-value & Conclusion \\
\hline Rape & $80.40^{* * * *}$ & 0.000 & Fixed effect \\
Eve-teasing & $76.42 * * *$ & 0.000 & Fixed effect \\
Molestation & $103.35^{* * *}$ & 0.000 & Fixed effect \\
Abduction and kidnapping & $28.09^{* * *}$ & 0.005 & Fixed effect \\
Cruelty by husband & $51.83 * * *$ & 0.000 & Fixed effect \\
Dowry deaths & $67.91 * * *$ & 0.000 & Fixed effect
\end{tabular}

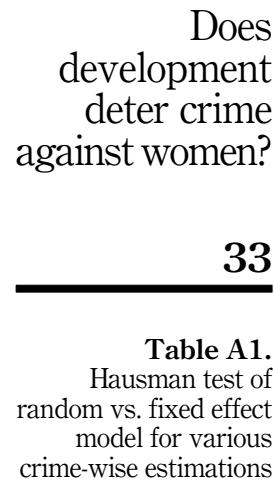

Does

development

deter crime

against women?

Note(s): Here, individual crime is the dependent variable and the estimation is conducted at the all-India level

\begin{tabular}{|c|c|c|c|c|c|c|c|}
\hline \multirow[b]{2}{*}{ Variables } & \multicolumn{2}{|c|}{ Levin-Lin-Chu } & \multicolumn{2}{|c|}{ ADF-Fisher Chi-square } & \multicolumn{2}{|c|}{ PP-Fisher Chi-square } & \\
\hline & $\mathrm{I}(0)$ & $\mathrm{I}(1)$ & $\mathrm{I}(0)$ & $\mathrm{I}(1)$ & $\mathrm{I}(0)$ & $\mathrm{I}(1)$ & \\
\hline HDI & 2.58 & $-9.10 * * *$ & 51.12 & $150.34 * * *$ & 31.77 & $209.70^{* * * *}$ & \\
\hline POLE & $-4.89 * * *$ & - & $94.37 * * *$ & - & $124.68 * * *$ & - & \\
\hline PND & $-14.15^{* * * *}$ & - & $195.33^{* * * *}$ & - & $200.94 * * *$ & - & \\
\hline WEM & $-7.15^{* * * *}$ & - & $111.55^{* * * *}$ & - & $100.22^{* * * *}$ & - & \\
\hline DISP & $-9.75^{* * * *}$ & - & $166.40^{* * * *}$ & - & $216.40 * * *$ & - & \\
\hline CONV & $-15.83^{* * * *}$ & - & $187.58^{* * * *}$ & - & $231.27 * * *$ & - & \\
\hline ARRST & $-8.43 * * *$ & - & $115.17^{* * * *}$ & - & $139.57^{* * * *}$ & - & \\
\hline PSW & $-20.36^{* * * *}$ & - & $241.62^{* * * *}$ & - & $242.24 * * *$ & - & \\
\hline URB & 0.97 & $37.70^{* * * *}$ & 35.82 & $324.73 * * *$ & 33.27 & $351.83^{* * *}$ & \\
\hline $\mathrm{SC}$ & $-19.11^{* * *}$ & - & $200.80^{* * * *}$ & - & $243.05^{* * * *}$ & - & Panel unit root test \\
\hline $\mathrm{FF}$ & $-13.69 * * *$ & - & $-364.10 * * *$ & - & $248.72^{* * *}$ & - & with intercept \\
\hline \multicolumn{7}{|c|}{ Note(s): $* * * p<0.01$} & and trend \\
\hline
\end{tabular}

\section{Corresponding author}

Kirtti Ranjan Paltasingh can be contacted at:kirtti@smvdu.ac.in

For instructions on how to order reprints of this article, please visit our website:

www.emeraldgrouppublishing.com/licensing/reprints.htm

Or contact us for further details: permissions@emeraldinsight.com 